\title{
GYTOPLASMIC AND NUCLEAR MATURATION OF RABBIT OOCYTES IN VITRO
}

\author{
C. THIBAULT and Micheline GÉRARD \\ Station de Physiologie animale, I. N. R. A., \\ 78350 Jouy en Josas (France)
}

\section{SUMMARY}

Rabbit oocytes from preovulatory follicles resume meiosis up to metaphase II in normal delay when cultured in TC 199 supplemented with rabbit and calf sera and chick embryo extract. They are fertilizable, but such oocytes are unable to assume transformation of the sperm head into a normal nucleus, the male pronucleus.

Rabbit preovulatory follicle can be maintained in healthy conditions for at least 24 hours, if gas pressure is increased to 5 to 10 bars $/ \mathrm{cm}^{2}$ during culture (air $+0.5 \mathrm{p}$. IOO $\mathrm{CO}_{2}$ ), and in the presence of gonadotropins.

In such follicles, oocytes remain in the dictyate stage when crude horse pituitary extract is added to the culture medium. However, if subphysiological doses of ovine LH or FSH (or better, FSH and LH) are present in the culture medium, meiosis resumes and complete cytoplasmic maturation occurs in all oocytes, as proved by normal fertilization and growth of the male pronucleus.

Thus, two steps may be considered in complete oocyte maturation :

I. The resumption of meiosis by rupture of the inhibitory effect of the granulosa layer. This is not basically dependent on gonadotropins.

2. On the contrary, passage of the male pronucleus growth factor, or its precursor, inside the oocyte is gonadotropic-follicular dependent.

These processes are both the necessary prerequisites to normal fertilization, and they can be activated in a pure in vitro system.

The follicle constitutes a balanced physiological unit, the oocyte preventing luteinization of the granulosa and theca cells (NEKOLA and NALBANDOV, I97I), and the granulosa, the resumption of oocyte meiosis (FooTE and ThIBAUL, r, r969).

This reciprocal control permits oocytes which have finished growth, to be stored for years in a dictyate stage in the ovary of female mammals.

Experimental detaching of the oocyte and its culture, or spontaneous detaching by granulosa picnosis, in the Graafian follicles in atresia, generally results in the resumption of meiosis up to metaphase II. 
These oocytes can be fertilized and are also capable of division after parthenogenetic activation (THIBAUL, $T$, I970, I973). Is the only function of the ovulatory gonadotropin surge to insure the physiologiçal and mechanical rupture of ties between the granulosa and the ovocyte?

The progress of the fertilization of oocytes having thus finished nuclear maturation in vitro when analyzed shows that fertilization develops abnormally, and in vitro maturation of the oocytes outside their follicle is incomplete (THrBauLT and GÉRARD, I97I).

In the present study, we tried to determine the contribution of the follicle to complete oocyte maturation.

\section{MATERIAI AND METHODS}

The oocytes or follicles used are taken from pubescent New Zealand doe rabbits usually nulliparous and in œstrus.

The largest follicles (6-12), considered as preovulatory follicles, are used.

\section{A. - Culture medium}

The culture medium is composed of :

- TC 199-50 parts (Microbiological Associates)

- doe rabbit serum-I 5 parts (prepared by us)

- calf serum - I5 parts (Sorga)

- embryonic chick extract - 20 parts (prepared by us)

The gonadotropic hormones used are either sheep LH or FSH (C. N. R. S.), or unpurified horse pituitary extract (preparation we use in other circumstances to multiply the number of preovulatory follicles and obtain superovulation in the rabbit).

The steroid hormones (progesterone, 20 $\alpha$-OH-progesterone $\mathrm{I} 7 \beta$-œestradiol) are solubilized in alcohol.

All manipulations are done at $30^{\circ} \mathrm{C}$, and the cultures at $37 \cdot 5^{\circ} \mathrm{C}$.

\section{B. - Obtention and culture of oocytes}

Oocytes are aspirated with a glass pipette rinsed in a medium containing $\mathrm{TC} I 99$ and ro p. roo of doe rabbit serum, then cultivated in the medium described above.

Culture is done in tubes containing $\mathbf{I} \mathrm{ml}$ of the medium. These tubes are placed in a glass dryer filled with a mixture of air $+5 \mathrm{p}$. $100 \mathrm{CO}_{2}$ which bubbles in the sterile water at the bottom of the dryer (ThIBAULT and GERARD, I97I).

Time $O$ is the moment when the oocytes are placed in final culture conditions. I5 to 25 minutes elapse between slaughter and time 0 .

\section{C. - Obtention and culture of follicles}

Under a binocular microscope the ovary is cut lengthwise into two unequal parts parallel to the ligament.

The narrowest part contiguous to the ligament is eliminated. It contains few or no follicles.

The other part is stretched crosswise and flattened by traction on the edges of the cut made when the ovary was sliced in two. The Graafian follicles then appear by transparency ; they are isolated from the interstitial tissue, other follicles and the ovarian epithelium by dilaceration with small brussels.

The follicles are then rinsed and cultured in Falcon dishes containing $0.8 \mathrm{ml}$ of the final medium. 40 to 50 minutes elapse between slaughter and the time they are put in culture. 
The dishes are placed in an air-tight metal box (fig. 5) which is filled with a mixture of air and a proportion of $\mathrm{CO}_{2}$, so that when gas pressure reaches $\mathrm{I} 0$ or 5 bars, depending on the experiments, the $\mathrm{pH}$ stays at 7.3-7.4 (about o.5 p. roo $\mathrm{CO}_{2}$ ).

When cultures are done at normal atmospheric pressure, the Falcon dishes are put in a glass dryer under $95 \mathrm{p}$. I 100 air and $5 \mathrm{p}$. I $100 \mathrm{CO}_{3}$.

After culture from 8 to $\mathbf{2 4}$ hours in these conditions, the follicles are depressurized slowly for ro to 20 minutes, then either fixed in toto or pierced, and their oocytes recovered and transferred into a fresh medium while waiting to be fertilized.

\section{D. - Test of oocyte fertilization ability}

The fertilization ability of oocytes cultured alone in vitro was tested by in vitro fertilization using the techniques ordinarily employed in the laboratory (THIBAULT and DaUzIER, I96r).

The fertilization ability of oocytes recovered after culture inside their follicles is tested by transferring these oocytes into the Fallopian tube of a doe rabbit mated $9 \mathrm{I} / 2$ hours previously. The ovarian follicles in the ovary lying next to the Fallopian tube used, are cauterized at the time of transfer. The fertilization ability and evolution of pronuclei of the oocytes matured in their follicle in vitro, then transplanted into this Fallopian tube, may then be compared to that of control oocytes laid in the opposite Fallopian tube several minutes later.

\section{E. - Cytological study of oocytes}

The oocytes and follicles are fixed in Bouin-Hollande and the oocytes included in gelose, using the habitual techniques (ThIвaULт, 1949). Serial sections are made at ro $\mu$, and the oocytes and follicles are examined after staining by hematoxyline eosin.

\section{RESULTS}

\section{A. - Oocytes cultured in vitro indepently of their follicle}

We showed (Thrbauli and Gerard, I97I) that in the medium conditions described, all preovulatory oocytes undergo maturation in vitro. This maturation is chronologically normal because it occurs at exactly the same speeds as in vivo maturation after mating or $\mathrm{HCG}$ injection.

TABLE I

Evolution of the sperm head from $3.5 \mathrm{hrs}$ to $9 \mathrm{hrs}$ after introducing capacited sperm in vitro Évolution de la tête du spermatozoïde dans l'auf de 3,5 à 9 heures après l'introduction du sperme capacité in vitro

\begin{tabular}{|c|c|c|c|c|c|c|c|c|c|c|c|}
\hline \multirow{2}{*}{$\begin{array}{c}\text { Time } \\
\text { after } \\
\text { mixing } \\
\text { (in h) }\end{array}$} & \multirow[t]{2}{*}{$\begin{array}{l}\text { No of } \\
\text { eggs } \\
\text { fertil. }\end{array}$} & \multicolumn{2}{|c|}{$\begin{array}{c}\text { No } \\
\text { modification } \\
\text { of spernı } \\
\text { head }\end{array}$} & \multicolumn{2}{|c|}{$\begin{array}{c}\text { Membrane } \\
\text { formation } \\
\text { but no } \\
\text { swelling }\end{array}$} & \multicolumn{2}{|c|}{$\begin{array}{c}\text { Small } \\
\text { head } \\
\text { pronucleus }\end{array}$} & \multicolumn{2}{|c|}{$\begin{array}{l}\text { Sub-normal } \\
\text { male } \\
\text { pronucleus }\end{array}$} & \multicolumn{2}{|c|}{$\begin{array}{l}\text { Cleaved } \\
\text { eggs }\end{array}$} \\
\hline & & $N^{\circ}$ & $\%$ & $\mathrm{~N}^{\circ}$ & $\%$ & $\mathrm{~N}^{0}$ & $\%$ & No & $\%$ & No & $\%$ \\
\hline 3.30 & 25 & 23 & 92 & 2 & 8 & & & & & & \\
\hline 6.00 & 12 & 8 & 66 & 3 & 25 & & & 1 & 9 & & \\
\hline 7.30 & 29 & 9 & 31 & 12 & 41 & 5 & 17 & 3 & 10 & & \\
\hline 9.00 & 7 & 4 & 57 & 2 & 30 & & & 1 & 13 & & \\
\hline 15.00 & 42 & 3 & 7 & & & 10 & 24 & 8 & 19 & 21 & 50 \\
\hline
\end{tabular}


When these oocytes are placed in vitro in the presence of capacitated spermatozoa, the way the spermatozoid penetrates, the formation of the female pronucleus, the development of the spermaster, and the migration of the male and female nuclei towards each other in the center of the oocyte, occur normally, but the spermatozoon head does not change (fig. 6). There is no male pronucleus formation (THIBAULiT and GERARD, I970, I97I). Several hours after fertilization when the two pronuclei normally enter into contact in the center of the oocyte, only the junction of a female pronucleus with an unchanged sperm head may be seen.

Several hours later in some oocytes a nuclear membrane appears surrounding a practically unmodified sperm head. In only a few cases did a male pronucleus of subnormal size develop (table $\mathrm{I}$ ).

Absence of sperm head evolution, or late and always abnormal male pronucleus head formation, shows that during natural oocyte maturation in the in vivo follicle a substance appears in the cytoplasm which causes transformation of the sperm head in the male pronucleus. This substance is not present in the oocyte which undergoes in vitro maturation, although meiosis may be normal otherwise. We have decided to call this substance MPGF, male pronucleus growth factor.

\section{B. - Origin of male pronucleus growth factor}

In order to determine when this factor appears in the in vivo oocyte after the ovulatory surge, we recovered oocytes from preovulatory follicles $2,3,5$ and 7 hours after mating or $\mathrm{HCG}$ injection.

TABLE 2

Time required for the presence of the MPGF in the oocyte during in vivo maturation

Temps nécessaire à l'apparition du MPGF dans l'ovocyte au cours de la maturation in vivo

\begin{tabular}{|c|c|c|c|c|c|c|c|}
\hline \multirow{2}{*}{$\begin{array}{l}\text { Time between } \\
\text { HCG, coitus } \\
\text { and culture } \\
\text { (h) }\end{array}$} & \multirow[b]{2}{*}{$\begin{array}{l}\text { In vitro } \\
\text { maturation } \\
\text { in hours }\end{array}$} & \multirow[b]{2}{*}{$\begin{array}{l}\text { No of } \\
\text { rabbits }\end{array}$} & \multirow[b]{2}{*}{$\begin{array}{l}\text { No of } \\
\text { oocytes }\end{array}$} & \multicolumn{2}{|c|}{ Fertilized eggs } & \multicolumn{2}{|c|}{ Sperm head evolution } \\
\hline & & & & No & $\%$ & $\begin{array}{c}\text { No or } \\
\text { abnormal } \\
(\%)\end{array}$ & $\begin{array}{c}\text { Normal } \\
(\%)\end{array}$ \\
\hline 2 & 12.00 & 4 & 31 & 20 & 64 & 100 & 0 \\
\hline 3 & 12.00 & 2 & 15 & 8 & 53 & 100 & 0 \\
\hline 5 & 12.00 & 3 & 14 & 0 & 64 & 100 & 0 \\
\hline 7 & 5.00 & 3 & 25 & 11 & 44 & 20 & 80 \\
\hline
\end{tabular}

The oocytes are then cultured in vitro until nuclear maturation is finished, and then they are fertilized in vitro. Only those oocytes recovered at 7 hours after the ovulatory surge are capable of insuring the transformation of the spermatozoon into a normal male pronucleus (table 2).

- MPGF thus appears late in the oocyte. 
Changes in the Golgi apparatus, which are described in corona cells after the ovulatory surge (MORICARD, I934, I963), led us to think that these cells were responsible for the synthesis of this factor, but only in presence of gonadotropins. Therefore, we tried to cultivate oocytes from preovulatory follicles in presence of various hormones : FSH, LH, prolactin, I7 $\beta$-oestradiol, progesterone or $20 \alpha-\mathrm{OH}$ progesterone. Only prolactin seems to have a slight effect favorizing the appearance of MPGF (table 3).

TABLE 3

Influence of various hormones during in vitro maturation of the rabbit oocyte on the male pronucleus formation

Influence de diverses hormones pendant la maturation in vitro de l'ovocyte de Lapine sur la formation du pronucleus male

\begin{tabular}{|c|c|c|c|c|c|c|c|c|}
\hline \multirow{2}{*}{ Hormones } & \multirow{2}{*}{$\begin{array}{l}\text { No of } \\
\text { rabbits }\end{array}$} & \multirow{2}{*}{$\begin{array}{l}\mathrm{N}^{0} \text { of } \\
\text { oocytes }\end{array}$} & \multicolumn{2}{|c|}{$\begin{array}{l}\text { Fertilized } \\
\text { eggs }\end{array}$} & \multirow{2}{*}{$\begin{array}{c}\% \\
\text { digyny }\end{array}$} & \multicolumn{3}{|c|}{$\begin{array}{l}\text { Sperm head evolution } \\
(\%)(\mathbf{1})\end{array}$} \\
\hline & & & No & $\%$ & & 0 & * & $* *$ \\
\hline FSH-ovine $2 \mu \mathrm{g} / \mathrm{ml}$ & 5 & 48 & 21 & 44 & 9 & 62 & 25 & 13 \\
\hline LH-ovine $2 \mu \mathrm{g} / \mathrm{ml}$ & 5 & 38 & 24 & 61 & 30 & 95 & 5 & 0 \\
\hline $\begin{array}{c}\text { FSH }+ \text { I.H } \\
2 \mu \mathrm{g}+2 \mu \mathrm{g} / \mathrm{ml}\end{array}$ & 4 & 33 & 30 & 90 & 40 & 93 & 7 & 0 \\
\hline Prolactin $10 \mu \mathrm{g} / \mathrm{ml}$ & 5 & 46 & $2 / 4$ & 52 & 86 & 21 & 17 & 61 \\
\hline $\begin{array}{l}\text { FSH }+ \text { prolactin } \\
2 \mu \mathrm{g}+10 \mu \mathrm{g} / \mathrm{ml}\end{array}$ & 4 & 25 & 19 & 76 & 50 & 69 & 12 & 19 \\
\hline $\begin{array}{c}\mathrm{LH}+\text { prolactin } \\
2 \mu \mathrm{g}+10 \mu \mathrm{g} / \mathrm{ml}\end{array}$ & 5 & 46 & 26 & 56 & 75 & 30 & 10 & 60 \\
\hline Estradiol $1 \mu \mathrm{g} / \mathrm{ml}$ & 3 & 25 & 12 & 48 & 19 & 55 & 45 & 0 \\
\hline $\begin{array}{l}\text { Progesterone } \\
10 \mu \mathrm{g} / \mathrm{ml}\end{array}$ & 4 & 24 & 12 & 50 & 17 & 50 & 50 & 0 \\
\hline $20 \alpha-\mathrm{OH}-\mathrm{Pg} 10 \mu \mathrm{g} / \mathrm{ml}$ & 2 & 20 & 16 & 80 & 0 & 100 & 0 & 0 \\
\hline
\end{tabular}

(1) 0 : No evolution.

* : Late swelling or membrane formation.

** : Small pronucleus.

\section{C. - Maturation in the follicle in vivo}

The late presence of MPGF during in vivo maturation when the first polar body is about to be emitted, its absence in the oocyte when cultivated alone or even with its corona cells with or without gonadotropic or steroid hormones, indicate that neither passage into the oocyte cytoplasm of the germinative vesicle nuclear content nor production of corona cells is responsible for this factor: it rather depends on the granulosa or theca cells.

This led us to inquire if it was possible to obtain MPGF synthesis by the in vitro follicle. 
a) Maintenance of the in vitro follicle without signs of degeneration.

The study of oocyte intrafollicular maturation in vitro, under gonadotropic hormone stimulation, necessitates culture conditions in which the different layers - theca, granulosa, corona cells - will not present any sign of picnosis because the oocyte is able to spontaneously resume meiosis when the granulosa degenerates in the atresic follicles.

Noting BAKER and NEAL's observation (I970) concerning the favorable role of pressure on mouse ovary follicles, we cultured preovulatory follicles under ro-bar pressure, with or without hormones. The follicles were examined $20-24$ hours after being put in culture.

Table 4 clearly shows that the presence of gonadotropic hormones and a high pressure are equally necessary for procuring granulosa and/or corona cells with no sign of picnosis (fig. I, 2, 3, 4).

TABLE 4

Number of experiments with picnosic $(\mathrm{P})$ or healthy $(\mathrm{H})$ follicles
under different conditions of culture

Nombre d'expériences avec des follicules normaux $(\mathrm{H})$ ou picnotiques (P) selon les conditions de culture

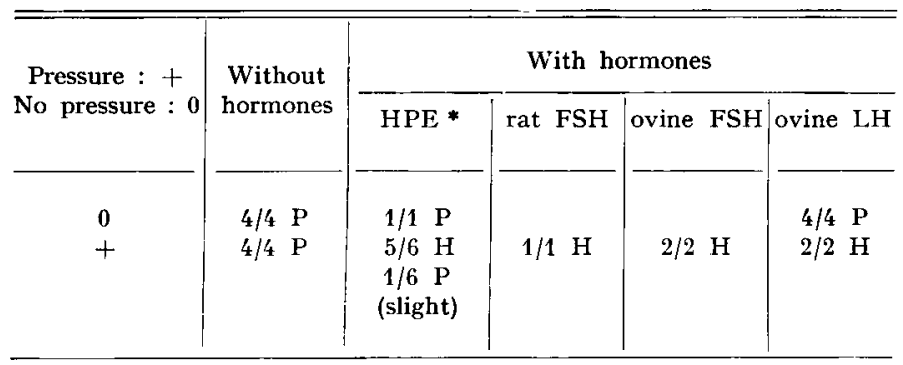

* Horse pituitary extract. Extrait hypophysaire de cheval.

b) Oocyte maturation.

Two FSH and/or LH levels were used : Io $\mu \mathrm{g} / \mathrm{ml}$ or I $\mu \mathrm{g} / \mathrm{ml}$.

With each of the two hormones, and for the two levels used, roo p. Ioo oocytes finished meiosis (table 5).

Eight hours after the beginning of culture, the first polar body is almost formed. In vitro maturation thus seems to require about two hours longer than in vivo maturation. This may be due to the fact that in vitro the hormone must be diffused through the theca, while in vivo it is carried by the circulation to the granulosa basal membrane.

Eleven hours after beginning of culture, the second metaphase maturation spindle is formed.

Thirteen hours later, or 24 hours after beginning of culture, the oocytes remain in the same state and the cells of the various follicle layers are healthy. 
TABLE 5

Meiotic division induced by gonadotropins in follicular oocytes

Induction de la méiose par les gonadotropines dans les ovocytes folliculaires

\begin{tabular}{|c|c|c|c|c|c|c|c|}
\hline \multirow{2}{*}{$\begin{array}{c}\text { Duration } \\
\text { of culture } \\
\text { (hours) }\end{array}$} & \multirow{2}{*}{$\begin{array}{l}\text { No of } \\
\text { follicles }\end{array}$} & \multicolumn{6}{|c|}{ Responses to } \\
\hline & & $\begin{array}{c}\text { FSH } \\
10 \mu \mathrm{g} / \mathrm{ml}\end{array}$ & $\begin{array}{l}\text { FSH } \\
1 \mu \mathrm{g}\end{array}$ & $\begin{array}{c}\mathrm{LH} \\
\mathbf{1 0} \boldsymbol{\mu g}\end{array}$ & $\begin{array}{l}\text { FSH + LH } \\
10+10 \mu \mathrm{g}\end{array}$ & $\begin{array}{l}\mathrm{LH} \\
1 \mu \mathrm{g}\end{array}$ & $\begin{array}{c}\mathrm{FSH}+\mathrm{LH} \\
1+1 \mu \mathrm{g}\end{array}$ \\
\hline 24 & $\begin{array}{l}3 \\
6 \\
5 \\
6\end{array}$ & $3 \mathrm{M}_{2} *$ & $\begin{array}{ll}6 & M_{2} \\
5 & M_{2}\end{array}$ & $6 \mathrm{M}_{2}$ & & & \\
\hline 24 & 4 & & & & $4 \mathrm{M}_{2}$ & & \\
\hline 24 & 5 & & & & & $5 \mathrm{M}_{2}$ & \\
\hline 24 & 4 & & & & & & ${ }_{4} \mathrm{M}_{2}$ \\
\hline 11 & $\begin{array}{l}3 \\
3\end{array}$ & $3 \mathrm{M}_{2}$ & & $3 \mathrm{~T}_{1}{ }^{* *}$ & & & \\
\hline 8 & $\begin{array}{l}3 \\
3\end{array}$ & $3 \mathrm{~T}_{1}$ & & $3 \mathrm{M}_{1}$ & & & \\
\hline
\end{tabular}

* $\mathrm{M}_{2}$ : Metaphase II.

** $\mathrm{T}_{\mathbf{1}}$ : Telophase I.

The follicle rarely ruptures, but it may appear to elongate, thus expressing a localized thinning of the wall.

In vivo, 24 hours after the LH peak, or I3 hours after ovulation, follicle luteinization is already quite advanced. 24 hours after gonadotropic hormone contact, in our in vitro experiments, follicle luteinization only occurs rarely. This may be explained by persistence of the inhibitory effect of the oocyte present in the follicle on granulosa cell luteinization (E, Fouly et al., I970 ; NALBANDOv, I970).

Sometimes partial luteinization was observed with disappearance of the basal membrane and the granulosa invaded by theca cells already having a luteal aspect.

\section{c) Presence of $M P G F$.}

MPGF is found in the oocyte when it is cultured inside the follicle for I2 hours in presence of $\mathrm{FSH}$ and/or $\mathrm{LH}$ at a dose of $\mathrm{ro} \mu \mathrm{g} / \mathrm{ml}$ or $\mathrm{I} \mu \mathrm{g} / \mathrm{ml}$. Soon after fertilization, the sperm head swells, and the male pronucleus forms a little while before the female pronucleus, as in control oocytes naturally ovulated and present in the opposite Fallopian tube. The process of fertilization is exactly the same in oocytes matured in vitro in their follicle as in control oocytes (fig. 7,8 ; table 6). Nuclear and cytoplasmic oocyte maturation thus occurs completely in vitro, but inside the follicle and in presence of $\mathrm{FSH}$ or $\mathrm{L} / \mathrm{H}$. 
TABLE 6

Fertilization of ovocytes matured inside their follicles in presence of gonadotropins Fécondation des ovocytes maturés dans leurs follicules en présence de gonadotropines

\begin{tabular}{|c|c|c|c|c|}
\hline \multirow{2}{*}{$\begin{array}{l}\text { Hormones } \\
1 \mu \mathrm{g} / \mathrm{ml}\end{array}$} & \multicolumn{3}{|c|}{ Oocytes matured in their follicles } & \multirow{2}{*}{$\frac{\text { Control eggs }}{\begin{array}{c}\text { Stage of } \\
\text { fertilization }\end{array}}$} \\
\hline & Number & Fertilized & $\begin{array}{c}\text { Stage of } \\
\text { fertilization * }\end{array}$ & \\
\hline $\int 5$ bars & $\begin{array}{l}9 \\
7\end{array}$ & $\begin{array}{l}7 \\
1\end{array}$ & $\begin{array}{l}\text { Stage } 3 \\
\text { Stage } 2\end{array}$ & $\begin{array}{l}\text { Stage } 3 \\
\text { Stage } 2\end{array}$ \\
\hline$\{10$ bars & 6 & 3 & $\begin{array}{l}1 \text { stage } 2 \\
2 \text { stage } 3\end{array}$ & 一 \\
\hline Total & 22 & 11 & & \\
\hline 5 bars & 6 & 5 & $\begin{array}{l}4 \text { stage } 4 \\
1 \text { stage } 2\end{array}$ & Stages 4 and 5 \\
\hline$\stackrel{\mathrm{LH}}{10}$ bars & 10 & 5 & $\begin{array}{l}2 \text { stage } 4 \\
2 \text { stage } 3 \\
1 \text { stage } 2\end{array}$ & Stages 4 and 5 \\
\hline Total & 16 & 10 & & \\
\hline $\begin{array}{r}\text { FSH } \\
+\mathrm{LH}\end{array}\{10$ bars & $\begin{array}{l}9 \\
6\end{array}$ & $\begin{array}{l}9 \\
6\end{array}$ & $\begin{array}{l}\text { Stage } 4 \\
\text { Stage } 3\end{array}$ & $\begin{array}{l}\text { Stage } 4 \\
\text { Stage } 3\end{array}$ \\
\hline Total & 15 & 15 & & \\
\hline
\end{tabular}

* Stages according to Thibault, 1967.

\section{DISCUSSION AND CONCLUSIONS}

Final nuclear and cytoplasmic maturation of the oocyte in mammals is insured by two different mechanisms.

The oocyte outside the follicle, with no gonadotropic hormone, in defined culture conditions, resumes meiosis spontaneously, and oocytes from preovulatory follicles attain the second metaphase of maturation exactly as in vivo.

The resumption of meiosis does not depend on steroids synthesized under gonadotropic effect, as in amphibians or fish, because as soon as oocytes are put in culture, the dictyate nucleus changes, metaphase I being formed at hour 4 after beginning of culture. Moreover, the fluid of mature rabbit follicles contains almost all the sex steroids, and $\mathrm{L}_{4} \mathrm{H}$ only stimulates their synthesis (MILLS and SAVARD, I972). We have proved that rupture of the inhibitory effect of the granulosa explains this rapid resumption of in vitro meiosis (Foote and THIBAULT, I969).

We have also shown in vitro that FSH and LH electively act on corona 
cells by causing their dissociation (ThIBaul, $T$, I970), so that in vivo the oocyte is very quickly disconnected physically from the granulosa. This situation is very similar to that of the in vivo oocyte after ovulatory surge.

If the follicle is maintained in perfect in vitro survival without adequate gonadotropins, the oocyte remains in the dictyate stage (cow, sow : FooTE and THIBaUlt, r969; ewe, woman, rabbit : Foote, Matrey, Trbbitrs and Thibault, I973 ; rat : TSAFRIRI et al., I972). On the other hand, meiosis is complete inside the cultured follicle in presence of sheep FSH and LH, as TSAFRIRI et al. (I972) have shown with rat follicles.

Cytoplasmic maturation can only occur inside the follicle, either in vivo or in vitro, and in presence of gonadotropins. The follicle furnishes the oocyte with the male pronucleus growth factor (MPGF) very late (hour 5-7). Since at that time cellular ties between oocyte and granulosa no longer exist, it is probable that, MPGF, or its precursor, is passed by means of the follicular fluid. If this is true this factor should be found in the follicular fluid.

\title{
REMERCIEMENTS
}

Ces recherches ont été partiellement financées par la D. G. R. S. T. (Contrat numéro 7r.7.3027) que nous remercions.

Les hormones FSH et LH nous ont été aimablement fournies par le Laboratoire des Hormones polypeptidiques du C. N. R. S. Nous remercions son directeur, M. JuTIsz.

Nous remercions également MM. DAGORne, JAME et MORET pour l'aide technique qu'ils nous ont apportée et qui nous a permis de réaliser les expériences de nuit que les délais de culture rendaient nécessaires.

\author{
RÉSUMÉ \\ MATURATION NUCLÉAIRE ET CYTOPLASMIQUE \\ DE L'OVOCYTE DE LAPINE IN VITRO
}

La reprise de la méiose a été souvent observée dans les ovocytes de nombreux mammifères prélevés dans des follicules de de Graaf et cultivés in vitro, mais tous les ovocytes n'atteignent pas la métaphase IT et leur aptitude a être fécondés et à se développer n'a pas été éprouvée.

Tous les ovocytes de Lapine prélevés dans des follicules préovulatoires de femelle en œestrus et cultivés dans un milieu contenant du TC I99, du sérum de Veau et de Lapin et de l'extrait embryonnaire de Poulet, achèvent leur méiose jusqu'à la métaphase II dans un délai identique à celui observé in vivo après coït ou induction de l'ovulation par HCG. Ces ovocytes sont fécondables mais ne permettent pas la transformation de la tête spermatique en un pronucleus mâle.

Les follicules préovulatoires peuvent être cultivés pendant au moins 24 heures sans picnose dans aucune des assises cellulaires du follicule ni dans les cellules périovocytaires à condition de maintenir l'atmosphère d'air et de $\mathrm{CO}_{2}$ à une pression comprise entre 5 et ro bars $/ \mathrm{cm}^{2}$ et en présence de gonadotropines. de cheval.

Dans ces follicules, les ovocytes demeurent à l'état dictyé en présence d'extrait hypophysaire

Si des quantités subphysiologiques de LH et/ou de FSH ovines sont ajoutées au milieu, la méiose reprend jusqu'à la métaphase II dans tous les ovocytes.

De plus, la maturation cytoplasmique complète se produit, comme le prouve le développement normal du pronucleus mâle si ces ovocytes sont fécondés. Les différents stades de la fécondation sont rigoureusement semblables à ceux des oufs témoins maturés et fécondés in vivo. 

tion :

Ainsi, on doit considérer deux étapes dans la maturation finale de l'ovocyte avant l'ovula-

I $^{\circ}$ La maturation nucléaire qui s'étend de la rupture du noyau dictyé à la métaphase II. Cette maturation est rendue possible par la rupture des liens cellulaires qui permettent à la granulosa d'exercer son action inhibitrice sur l'ovocyte. Cette étape ne dépend pas fondamentalement des gonadotropines puisqu'elle peut être réalisée par séparation expérimentale de la granulosa et de l'ovocyte sans aucun apport hormonal.

$2^{\circ}$ Au contraire, la maturation cytoplasmique qui correspond à la présence dans l'ovocyte de facteurs nécessaires à la croissance du pronucleus mâle (MPGF) implique l'action des gonadotropines sur les cellules du follicule lui-même et probablement sur la granulosa. Le passage de ce facteur ou de son précurseur dans l'ovocyte se fait par le liquide folliculaire.

Ces deux étapes de la maturation finale de l'ovocyte, préparatoires à la fécondation, peuvent être réalisés complètement in vitro.

\section{REFERENCES}

Baker T. G., Neal P., I970. Gonadotrophin-induced maturation of mouse Graafian follicles in organ culture. 377-396 in Biggers J. D., Schuetz A. W. Oogenesis. Univ. Park Press, Baltimore.

El-Fouly M.-A., Cook B., Nekola M., Nalbandov A. V., 197o. The role of the ovum in follicular luteinization. Endocrinology, 87, 288-293.

Foote W. D., Matlex D. L., Tibitts F. D., Thibault [C., I973. Follicular inhibition of mammalian ovocyte maturation in vitro. in press.

Foote W. D., Thibault C., 1969. Recherches expérimentales sur la maturation in vitro des ovocytes de truie et de veau. Ann. Biol. anim. Bioch. Biophys., 9, 329-349.

Mills T. M., SAvard K., I972. In vitro steroid synthesis by follicles isolated from the rabbit ovary. Ste roids, 20, 247-262.

Moricard R., I934. Des relations possibles entre le déclenchement des mitoses de maturation de l'ovocyte et les hormones contenues dans le liquide folliculaire. Rev. fr. Gyn. Obst., 29, 734 .

Moricard R., I963. Étude en microscopie électronique des vacuoles golgiennes complexes et de la vésicule germinative (ovules de lapine et ovules humains). Problèmes d'Hormonologie et de Cytogénétique. C. R. Ass. Anat., Bruxelles, 122, 275 .

Nalbandov A. V., I970. Interactions between oocytes and follicular cells, 513-522 in BigGers J.-D., Schuetz A. W. Oogenesis, Univ. Park Press, Baltimore.

Nekola M. V., Nalbandov A. V., I97I. Morphological changes of rat follicular cells as influenced by oocytes. Biol. Reprod., 4, I54-I60.

Thibault C., 1949. L'œuf des mammifères : son développement parthénogénétique. Ann. Sci. nat. Zool., I I e série, I33-218.

Thibault C., I967. Analyse comparée de la fécondation et de ses anomalies chez la brebis, la vache et la lapine. Ann. Biol. anim. Bioch. Biophys., 7, 5-23.

Thibault C., I970. Final stages of mammalian oocyte maturation, 397-41 I in Biggers J.-D., Schuetz A. W. Oogenesis. Univ. Park Press, Baltimore.

Thibault C., I973. In vitro maturation and fertilization of rabbit and cattle oocytes, in SegaL S. J., Crozier R., Corfman P. A., Condliffe P. G. The Regulation of mammalian reproduction, Charles C. Thomas, Springfield, Ill., U. S. A.

Thibault C., Dauzier L., I96r. Analyse des conditions de la fécondation in vitro de l'œuf de la lapine. Ann. Biol. anim. Bioch. Biophys., 1, 277-294.

Thibault C., Gerard M., r97o. Facteur cytoplasmique nécessaire à la formation du pronucleus mâle dans l'ovocyte de lapine. C. R. Acad. Sci., 270, D, 2025-2066.

Thibault C., GÉrard M., r97r. Maturation et fécondation in vitro de l'ovocyte de la lapine, r3-25. Colloque Pfizer, Amboise, Masson et Cle, Paris.

Tsafriri A., Lindner H. R., Zor U., LAmprecht S. A., I972. In vitro induction of meiotic division in follicle-enclosed rat oocytes by LH, cyclic AMP and prostaglandin $\mathrm{E}_{2}$. J. Reprod. Fert., 81, 39-50. 
PLATES 


\section{PLANCHE I}

FIG. I. - Follicule préovulatoire de Lapine cultivé 24 heures en présence d'extrait hypophysaire de Cheval à la pression atmosphérique (air +5 p. IOO $\mathrm{CO}_{2}$ ). Remarquer les zones importantes de picnose dans la granulosa $(\mathrm{P})$.

FIG. 2. - Culture sans hormones hypophysaires sous une pression de Io bars (air $+0,5$ p. IOo $\mathrm{CO}_{2}$ ). Petites zones de picnose. La méiose a repris jusqu'à la métaphase I dans l'ovocyte.

FIG. 3. - Culture en présence d'extrait hypophysaire de Cheval et sous une pression de Io bars. Aucune picnose n'est visible. L'ovocyte est toujours au stade dictyé.

FIG. 4. - Culture en présence de I $\mu \mathrm{g} / \mathrm{ml}$ de $\mathrm{L} / \mathrm{H}$ ovine et sous une pression de ro bars. Toutes les cellules sont saines et le premier globule polaire s'est formé (visible à la gauche de l'ovocyte). On voit également dans l'ovocyte les chromosomes de la métaphase II. Ils ont été séparés en trois groupes par le rasoir.

\section{PLATE I}

FIG. I. - Rabbit preovulatory follicle cultured for 24 hours in presence of horse pituitary extract at normal atmospheric pressure (air $+5 \mathrm{p}$. IOO $\mathrm{CO}_{2}$ ). Note large areas of completely picnotic granulosa cells $(\mathrm{P})$.

FIG. 2. - Culture without pituitary hormones under Io bars of pressure (air $+0.5 \mathrm{p}$. IoO $\mathrm{CO}_{2}$ ). Small areas of picnosis $(\mathrm{P})$. Oocyte has resumed meiotic division up to metaphase $\mathrm{I}$.

FIg. 3. - Culture in presence of horse pituitary extract and unerd Io bars of pressure. No picnosis was visible in any layers of the follicle. Oocyte has remained in the dictyate stage.

FIG. 4. - Culture in presence of $\mathrm{I} \mu \mathrm{g}$ of ovine $\mathrm{L} H / \mathrm{ml}$ and under Io bars of pressure. All the cells of the follicle are healthy and first polar body is clearly visible on the left side of the oocyte (PB). Metaphase II, chromosomes are also visible in the oocyte. They are scattered in three groups by sectionning. 

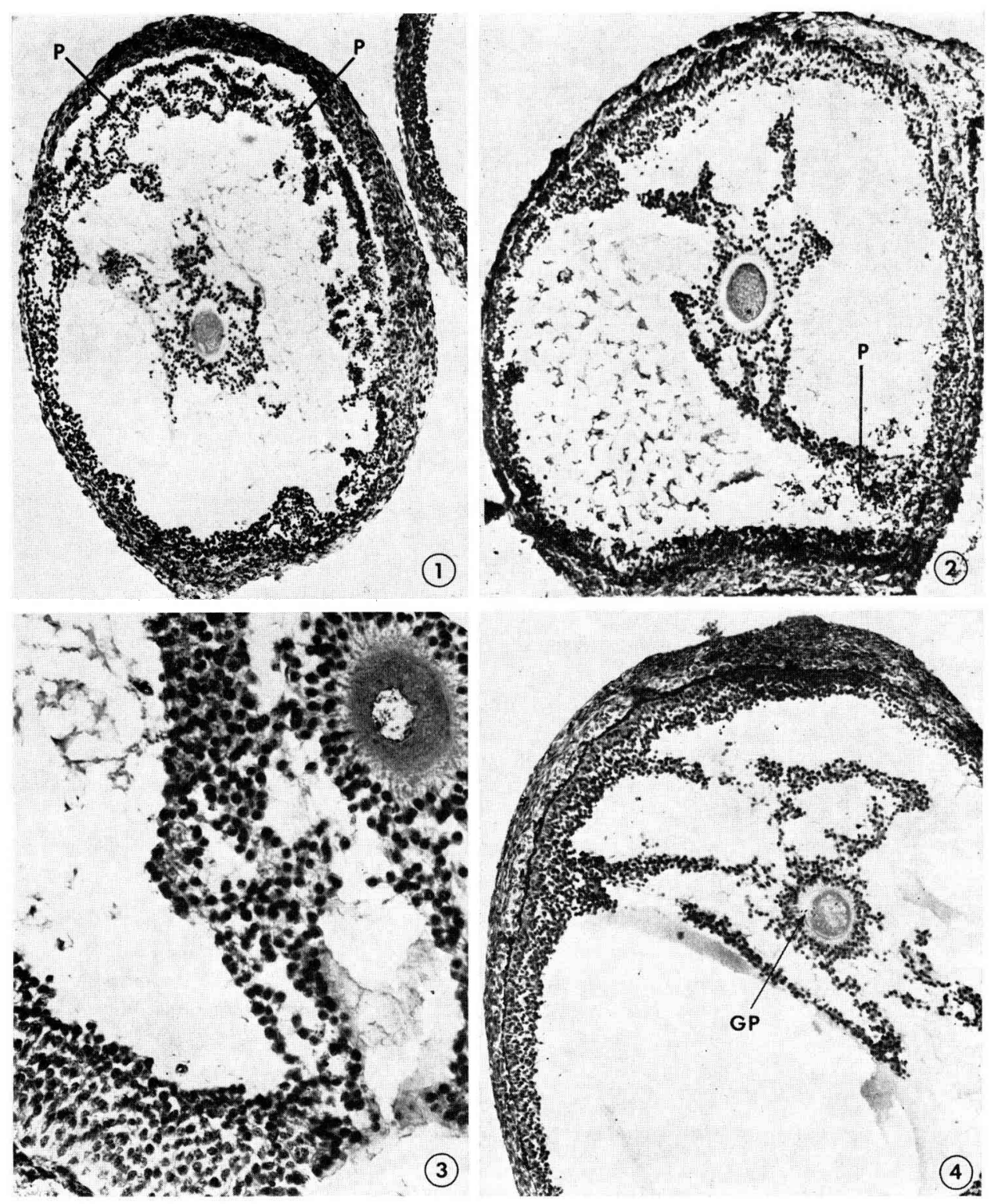

(3)

(4)

C. THIBAUL'T and M. GÉRARD 


\section{PLATE II}

FrG. 5

Details of metal box used for culture under pressure

FIG. 6

In vitro matured oocyte outside its follicle and in vitro fertilized. Note the absence of sperm head evolution.

FIG. 7

In vitro matured follicular oocyte then fertilized in vivo in the right fallopian tube of a rabbit mated 9 hrs before transfert. Evolution of male pronucleus is absolutely normal.

FIG. 8

Normally ovulated and fertilized egg from the left fallopian tube of the same rabbit.

\section{PLANCHE II}

FIG. 5

Détails du caisson métallique utilisé pour les cultures sous pression.

\section{FIG. 6}

Ovocyte maturé in vitro hors de son follicule et fécondé in vitro. Remarquer l'absence d'évolution de la tête spermatique.

\section{FIG. 7}

Ovocyte maturé in vitro dans son follicule, sous pression et en présence de FSH et $\mathrm{LH}$, fécondé in vivo dans l'oviducte droit d'une lapine accouplée 9 heures avant le transfert. L'évolution du pronucleus mâle est absolument normale.

Fig. 8

Euf témoin de l'oviducte gauche de la même lapine, ovulé normalement. 

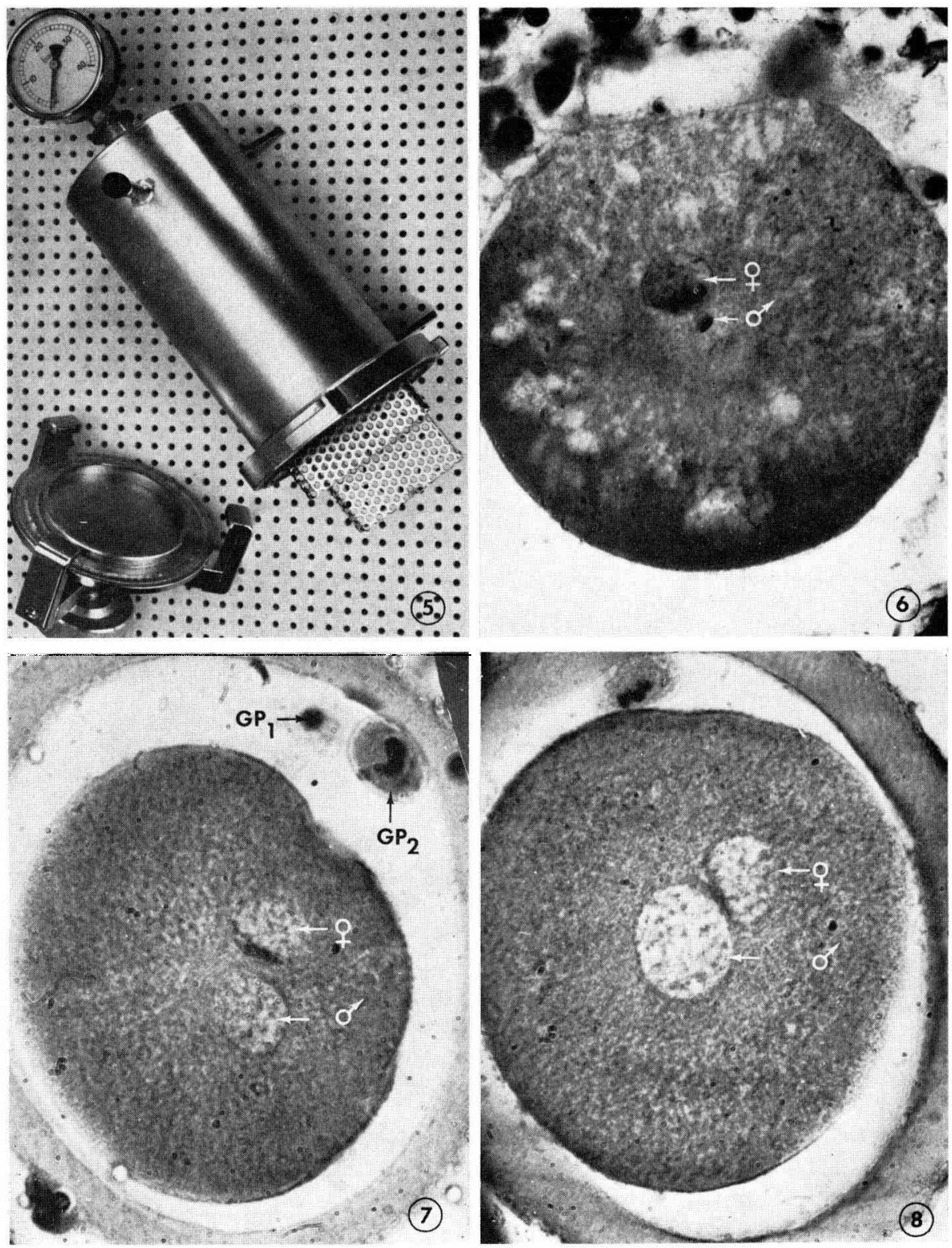

C. THIBAULT and M. GÉRARD 